\title{
Pro-health awareness of women in the context of knowledge about risk factors for cervical carcinoma
}

\section{Świadomość prozdrowotna kobiet $w$ kontekście wiedzy o czynnikach ryzyka raka szyjki macicy}

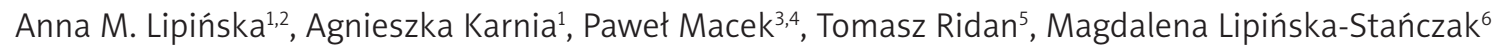 \\ 'Department of Organ of Hearing and Balance Rehabilitation, Institute of Physiotherapy, Faculty of Medicine and Health Sciences, \\ Jan Kochanowski University, Kielce, Poland \\ Head of the Department: Prof. Stanisław Bień MD, PhD \\ ${ }^{2}$ Department of Rehabilitation, Holycross Cancer Centre, Kielce, Poland \\ Head of the Department: Anna Opuchlik PhD \\ ${ }^{3}$ Department of Epidemiology and Cancer Control, Holycross Cancer Center, Kielce, Poland \\ Head of the Department: Paweł Macek PhD \\ ${ }^{4}$ Faculty of Medical Sciences, School of Economics, Law and Medical Sciences, Kielce, Poland \\ Head of the Faculty: Grzegorz Gałuszka PhD \\ ${ }^{5}$ Kinesitherapy Unit, Department of Physiotherapy, University of Physical Education, Krakow, Poland \\ Head of the Department: Jakub Szczechowicz PhD \\ ${ }^{6}$ Department of Pathobiomechanics, Institute of Physiotherapy, Faculty of Medicine and Health Sciences, Jan Kochanowski University, \\ Kielce, Poland \\ Head of the Department: Prof. Andrzej Rydzewski MD, PhD
}

Medical Studies/Studia Medyczne 2016; 32 (2): 102-108

DOI: $10.5114 / \mathrm{ms} .2016 .61097$

Key words: risk factors for cervical carcinoma, prevention, pro-health behaviour, health education.

Słowa kluczowe: czynniki ryzyka raka szyjki macicy, profilaktyka, zachowania prozdrowotne, edukacja zdrowotna.

\begin{abstract}
Introduction: The problem of cancer is becoming epidemic in the world. Despite many campaigns that promote prophylaxis, the number of women dying of cervical carcinoma is still high. Broadly defined health education aimed at detecting the disease at an early stage should be an important point of the cervical carcinoma prophylaxis program.

Aim of the research: To determine the level of awareness of women surveyed in the context of the risk factors and an analysis of health behaviours.

Material and methods: The study was conducted among 108 randomly selected women living in Świętokrzyskie province. The women were between the ages of 20 and 60 years.

Results: The study showed that the respondents were able to read properly the causes of the risk of cervical carcinoma, but only about $30 \%$ went to a gynaecologist for prophylactic measures. Thirty percent of the respondents had cytology regularly done. Only $8 \%$ of the women in the studied group accepted an invitation to screening examinations. The majority of the surveyed women knew the risk factors for cervical carcinoma but they did not translate their knowledge into health behaviours. Most of the respondents did not have regular cytological examinations done. The majority of the surveyed women did not have screening examinations done.

Conclusions: Therefore, it is necessary to multiply efforts within the actions preventing cervical carcinoma, and promote a healthy lifestyle and pro-health education.
\end{abstract}

\section{Streszczenie}

Wprowadzenie: Problem chorób nowotworowych przybiera na świecie rozmiary epidemii. Pomimo wielu kampanii promocyjnych propagujących profilaktykę, wciąż liczba kobiet umierających z powodu raka szyki macicy jest wysoka. Szeroko pojęta edukacja zdrowotna mająca na celu wykrywanie choroby we wczesnym stadium powinna być ważnym punktem programu dotyczącego profilaktyki raka szyjki macicy.

Cel pracy: Określenie poziomu świadomości badanych kobiet w kontekście czynników ryzyka zachorowania oraz analiza zachowań zdrowotnych.

Materiał i metody: Badania przeprowadzono wśród 108 losowo wybranych kobiet zamieszkałych w województwie świętokrzyskim. Badane kobiety były w wieku od 20 do 60 lat. 
Wyniki: Przeprowadzone badania wykazały, że respondentki we właściwy sposób potrafia odczytać przyczyny ryzyka zachorowania na raka szyjki macicy, ale tylko ok. 30\% chodzi do ginekologa w celach profilaktycznych. Regularnie cytologię wykonuje 30\% badanych. Z grupy badawczej tylko 8\% kobiet skorzystało z zaproszenia na badania przesiewowe. W większości badane kobiety znają czynniki ryzyka rozwoju raka szyjki macicy, lecz nie przekładają posiadanej wiedzy na zachowania prozdrowotne. Większość ankietowanych nie wykonuje badań cytologicznych regularnie. W większości badane kobiety nie korzystają z badań przesiewowych.

Wnioski: W związku z powyższym należy zwielokrotnić wysiłki w ramach profilaktyki raka szyjki macicy na rzecz propagowania zdrowego stylu życia oraz edukacji prozdrowotnej.

\section{Introduction}

In today's world more and more attention is being paid to the relationship between treatment and prevention. The importance of disease prevention is often emphasised; therefore, it is worth knowing the specifics of pro-health behaviours, especially those referring to oncologic diseases [1]. The problem of cancer is becoming epidemic in the world. According to data published by the International Agency for Research on Cancer, there were around 12.7 million new cases and 7.5 million deaths in the world in the year 2008. It is predicted that in 2020, 20 million people will have cancer, half of whom will die [2].

Oncologic diseases are among the most common diseases in women [3]. Women's health is specific because many its aspects are focused on issues related to maternity. For this reason, cancer of the reproductive organs is an important health problem. In the world, cervical carcinoma is the second most common cancer and the leading cause of death among women [4-8]. The incidence of the disease is gradually decreasing, but still remains at too high a level. On the basis of the National Cancer Registry, in 1980 the number of new cases of cervical carcinoma was 3532; however, in 2010 the number decreased to 3078 . The peak incidence of the disease, which accounts for $60 \%$ of the total number, is between the ages of 45 and 65 years. The probability of the disease increases with age until the end of the sixth decade of life, and then it lowers at the time of transition to older age groups. In 2003-2005, the rate of 5-year survival was 54.4\%. In Poland in 2010, the number of deaths due to cervical carcinoma was 1700 , which represents $4 \%$ of the total number of women's deaths because of cancer. Over $50 \%$ of deaths occur between the ages of 50-64 years. A comparison of the epidemiological data shows that in Poland the incidence of the disease (by 15\%) and mortality (by 70\%) are higher than in other European Union countries $[9,10]$. However, the highest mortality is noted among new EU member countries: Romania and Lithuania. The lowest mortality is observed in Finland, Germany, and Sweden, where the introduction of screening examinations in the 1960s meant that mortality decreased by more than $80 \%$ [11-13].

The risk factors for malignant tumours of the uterine cervix are known. The cause-effect correlation between the virus of human papillomavirus (HPV), a major factor for risk of the disease, and cervical carci- noma has been documented indisputably [11, 14, 15]. In the prevention of cancer, a very important role is played by health awareness, which should be supported by practical actions, skills, and pro-health habits. It is known that cervical carcinoma is closely related to lifestyle. There is a relationship between a number of negative behaviours in the past and the occurrence of the disease in later life $[7,16,17]$. However, it is a common fact that possessed knowledge does not always translate into specific pro-health behaviours. Despite many campaigns promoting prevention, the number of women dying of this cancer is still increasing. Awareness and knowledge of the risk factors for cervical carcinoma mean that women take different actions aimed at detecting the disease in its early stages $[7,18]$. Broadly understood health education should be an important point of the prevention program. It is estimated that health depends on people's own activity and actions taken by people themselves [1, 19-21].

\section{Aim of the research}

The main aim of the research was to determine the level of awareness about the risk factors for cervical carcinoma, and an analysis of pro-health behaviours of women living in the Świętokrzyskie region. In order to accomplish the main aim of the work, the following research questions were asked:

1. How well do the women from the studied group know the risk factors for cervical carcinoma?

2. How often did the women from the studied group have cytological examinations done?

3. In what way did the women from the studied group benefit from screening?

4. In what way does knowledge about cervical carcinoma prevention affect pro-health behaviours among the surveyed women?

\section{Material and methods}

The research material was collected on the basis of a diagnostic survey, which was carried out with the use of a questionnaire survey. The obtained data underwent statistical and descriptive analysis with the use of Microsoft Excel and Gretl software. Percentages were calculated. Statistical analysis was shown with the use of the independence $\chi^{2}$-square test. The significance level less than or equal to 0.05 was considered as a statistically significant value. 


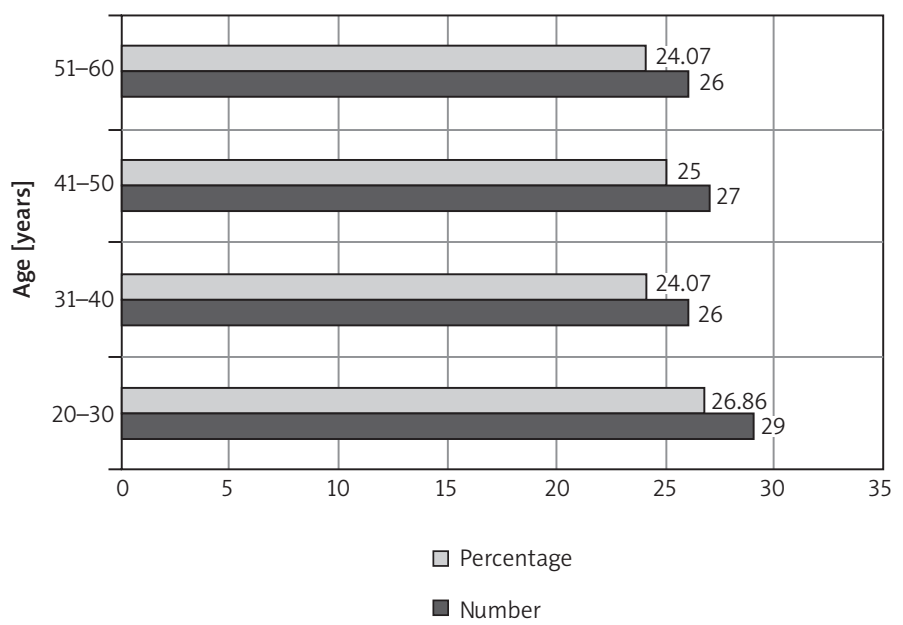

Figure 1. Graphical representation of the structure of the study group by age

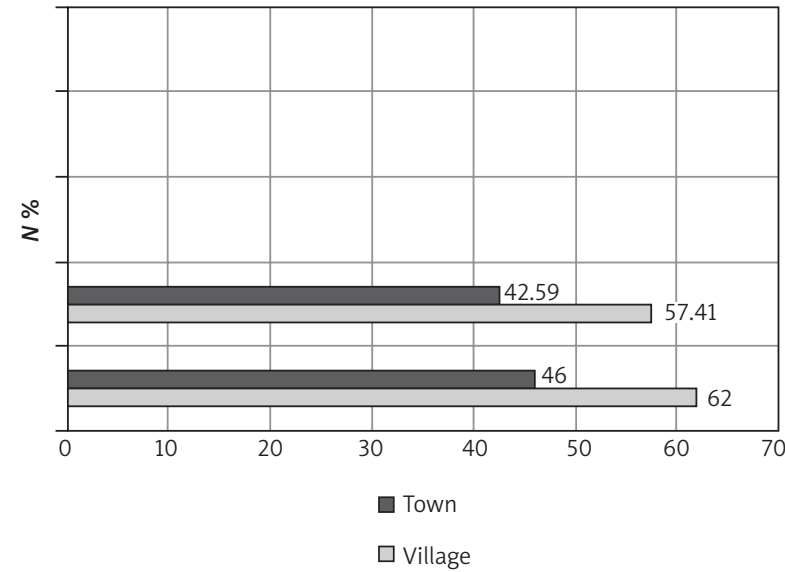

Figure 2. Graphical representation of the structure of the study group by place of residence

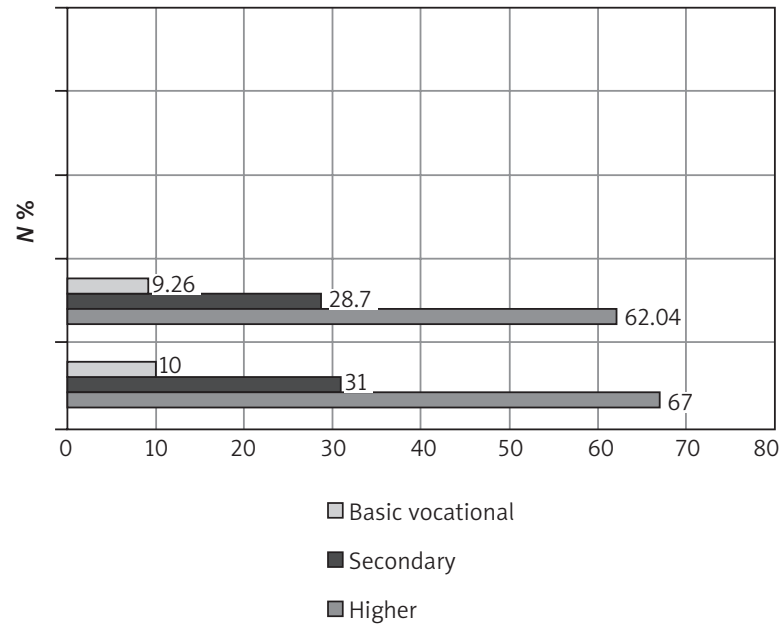

Figure 3. Graphical representation of the structure of the study group by education
In total 108 women took part in the study, including: $26.86 \%(n=29)$ aged $20-30$ years, $24.07 \%(n=26)$ aged $31-40$ years, $25 \%(n=27)$ aged $41-50$ years, and $24.07 \%(n=26)$ aged $51-60$ years (Figure 1$)$.

Among the respondents, $42.59 \%(n=46)$ of the women lived in a town, and 57.41\% $(n=62)$ lived in the countryside in Świętokrzyskie province (Figure 2).

Most of the respondents had higher education -67 (62.04\%), a smaller group consisted of women with secondary education - 31 (28.7\%), and with basic vocational education there were 10 (9.26\%) patients (Figure 3).

\section{Results}

Analysis of the results, answers to the survey questions, assessing the state of the women's knowledge within the scope of cervical carcinoma prophylaxis.

Seventy-five percent $(n=81)$ of the surveyed women mentioned a low level of personal and sexual hygiene as the most frequent factor for cervical carcinoma. It was followed by human papillomaviruses infection (HPV) $-67.96 \%(n=73)$ of the studied women, and smoking cigarettes by $62.96 \%(n=68)$. Age and a large number of sexual partners were mentioned by the same number of respondents $-61.11 \%(n=66)$, long-term use of contraceptives by $59.25 \%(n=64)$, and early sexual intercourse by $47.22 \%(n=51)$. Low socioeconomic status was indicated by $28.7 \%(n=31)$ of the respondents. The lowest number of women $24.07 \%(n=26)$ - associate the risk of cervical carcinoma with numerous births (Figure 4).

When asked about the last visit to the gynaecologist, $57.41 \%(n=62)$ of the women answered that it was the previous year, $25 \%(n=27)$ said $2-3$ years ago, $4.63 \%(n=5)$ said more than 3 years ago, $9.26 \%$ $(n=10)$ said that they did not remember the date of the last visit, and $3.7 \%(n=4)$ of the respondents declared that they had never been to visit the gynaecologist (Figure 5). 


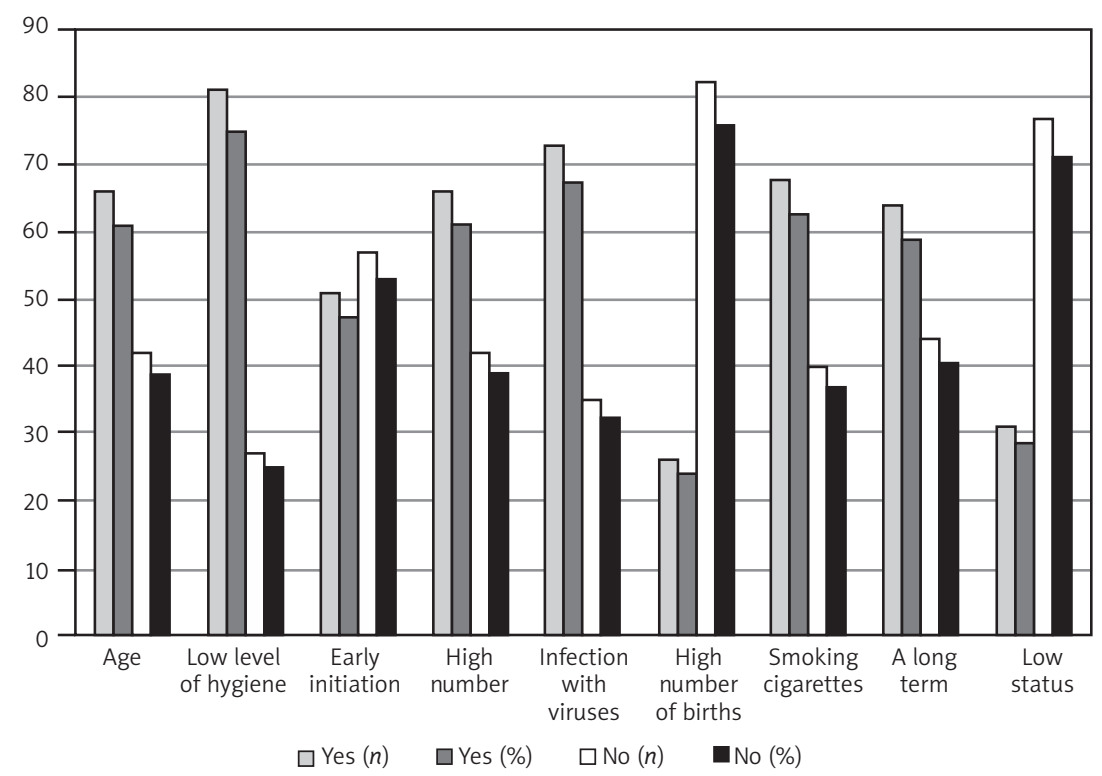

Figure 4. Graphical representation of risk factors responsible for the occurrence of cervical carcinoma according to the respondents

$35.19 \%$ of the women $(n=38)$ had regular cytological examinations done, and 35.19\% $(n=38)$ indicated that they occasionally had cytological examinations done; $1204 \%(n=13)$ of the women responded that they were only examined once, and $17.59 \%(n=19)$ of the respondents said that they did not have cytology done at all (Figure 6).

A cytological examination was done because of the patients' own initiative by $46.74 \%(n=43)$ of the studied, because of a referral from the doctor by $23.91 \%(n=22)$, because of pregnancy or childbirth by $13.04 \%(n=12)$, and because of ailments in the reproductive organs by $7.61 \%(n=7)$ of the patients. The same number of patients, i.e. $7.61 \%(n=7)$, had cytological examination done as screening examinations, and $1.09 \%(n=1)$ because of a close relative's illness (Figure 7).

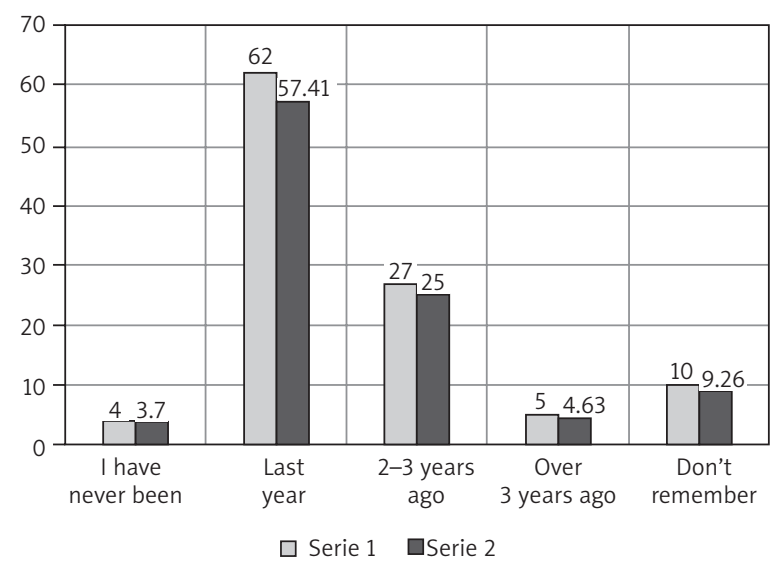

Figure 5. Graphical representation of last visit to the gynaecologist in the group of studied women

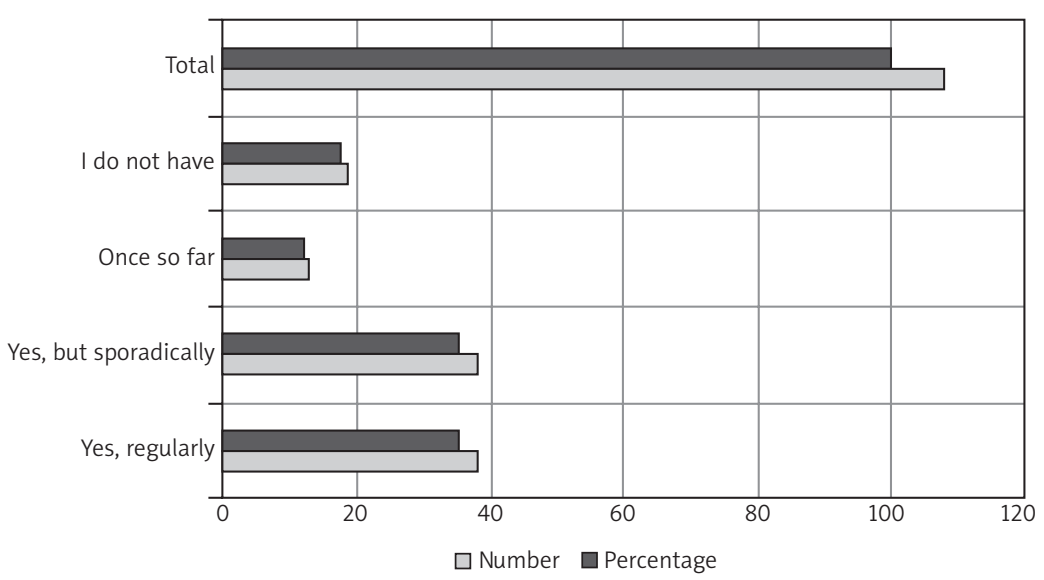

Figure 6. Graphical representation of the frequency of cytological examinations by the studied women 


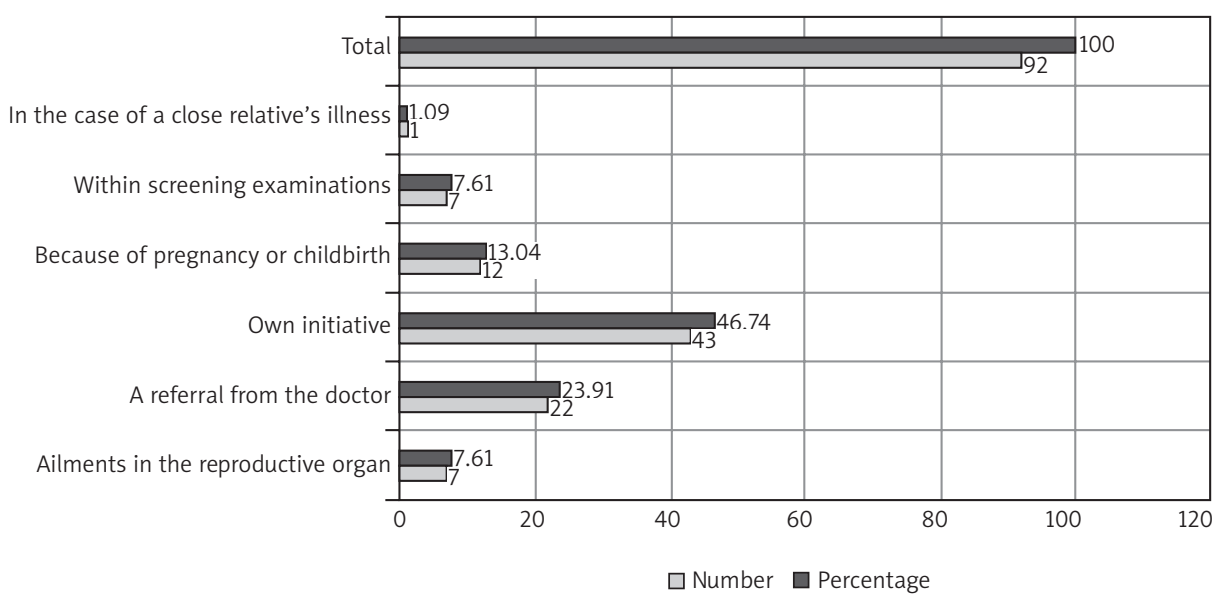

Figure 7. Graphical representation of the reasons for performing cytological examinations given by the surveyed women

Table 1. The impact of the level of women's knowledge on pro-health behaviours

\begin{tabular}{|c|c|c|c|c|c|c|c|}
\hline \multirow[t]{3}{*}{ Health behaviour } & \multicolumn{6}{|c|}{ Level of knowledge } & \multirow[t]{3}{*}{$P$-value } \\
\hline & \multicolumn{2}{|c|}{ Sufficient } & \multicolumn{2}{|c|}{ Requires deepening } & \multicolumn{2}{|c|}{ Together } & \\
\hline & $N$ & $\%$ & $N$ & $\%$ & $N$ & $\%$ & \\
\hline$P$ & 16 & 57.14 & 23 & 28.75 & 39 & 36.11 & 0.007 \\
\hline NP & 12 & 42.86 & 57 & 71.25 & 69 & 63.89 & \\
\hline Together & 28 & 100 & 80 & 100 & 108 & 100 & \\
\hline
\end{tabular}

The results of the research show that pro-health behaviours depend on the level of women's knowledge. Among the respondents with a sufficient level of knowledge, health behaviours (P) occurred in 16 (57.14\%) women, while incorrect behaviours (NP) occurred in $12(42.86 \%)$ women. In the group of women who need to deepen their knowledge, incorrect behaviours prevailed (NP) - 57 (71.25\%), and proper behaviours $(\mathrm{P})$ were presented only by $23(28.75 \%)$ of the studied. Statistical analysis with the use of the chisquare test shows that there is a significant statistical relationship between the women's knowledge about cervical carcinoma and the health behaviours presented by them. Value $p$ was at the level of 0.007 (Table 1).

\section{Discussion}

Risk factors for cervical carcinoma are known. Correct health behaviours resulting from a proper lifestyle can reduce the likelihood of cervical carcinoma. Preventive proceedings largely depend on the woman herself. With the proper knowledge about risk factors for cervical carcinoma, as well as an individual sense of responsibility, women can consciously participate in the implementation of preventive healthrelated policies. Regular visits to the gynaecologist and cytological examinations significantly reduce the risk of cancer because cervical carcinoma at an early stage does not cause any ailments, which is strongly emphasised in health education [7, 11, 22].

Analysis of our own research shows that the respondents can properly recognise the causes of cervical carcinoma. According to them, the most common risk factors are: a low level of personal and sexual hygiene, human papillomavirus infection, smoking cigarettes, age, long-term use of contraceptives, and early initiation of sexual intercourse. Nowicki et al. [12] received similar results in their research; however, Czechowska [8], on the basis of a survey, found that the most commonly reported (by the respondents) factors associated with risk were: early age of sexual initiation and smoking cigarettes.

According to Derlatka [20], women occasionally have preventive examinations done as a result of campaigns that promote such examinations, especially if they are free. It proves that women lack self-initiative and the need to control their health. According to Nowicki et al. [12], more than half of the studied women from both groups saw the gynaecologist once every two years or more often, but only about $50 \%$ of the respondents from each studied group went there for prophylactic reasons. Krajewski et al. [23] showed in their study that over half of the surveyed women 
knew the recommendations for the frequency of cytological examinations and yet almost $50 \%$ of them had never had such an examination done. As an explanation, the respondents mentioned a lack of ailments of the reproductive organs. The authors, in their own study, observed that only $35 \%$ of women had cytological examinations done regularly, which means that women are not fully aware of the importance of prophylactic examinations. It is necessary to emphasise that women who go to the gynaecologist's once a year and have a cytological examination done at least every 2-3 years can reduce the risk of cervical carcinoma by up to $80 \%$ [3].

Mastalerz-Migas et al. [13] states that the frequency of cytological examinations results most often from the doctor's, not the patient's, initiative. However, Jokel et al. [24], on the basis of research, proved that more than half of the respondents had the examination done due to their own initiative, and about 20\% were directed by the doctor. The authors' own results confirm these observations, because among women who had a cytological examination done, about $46 \%$ decided to have it due to their own initiative, and 24\% on the basis of a referral from the doctor. However, the fact that only $7.6 \%$ of the respondents used the invitation to have screening done is a very unfavourable confirmation that the surveyed women are not aware of pro-health behaviours and they are not guided by responsibility for their health.

In light of the analysis of the results, it can be stated that there is a statistically significant relationship between the knowledge about cervical carcinoma, possessed by the studied women, and their health behaviours. On this basis, it can be assumed that the change in the attitude of contemporary women towards preventive measures against cervical carcinoma can be obtained through conscious and continuous education. However, in the surveyed group, the lack of coherence between possessed knowledge about the risk factors and the realisation of prophylaxis principles in life was observed. This fact proves that, as part of prophylactic measures for cervical carcinoma, it is necessary to publicise the rules of prohealth behaviours and increase the efforts towards a healthy lifestyle among the whole of society.

The presented results of the research demonstrate the need for faster development of active screening for cervical carcinoma. However, it is necessary to realise that the efforts can result in failure if the health awareness of people in Poland does not change.

\section{Conclusions}

In the study group, the majority of women could identify the risk factors for cervical carcinoma. The majority of respondents did not have regular cytological examinations done. Most of the studied women did not have screening done. Pro-health behaviours depend on the level of women's knowledge. There is a statistically significant relationship between the knowledge about cervical carcinoma and health behaviours presented by the surveyed women. It is necessary to multiply the efforts, within preventive measures for cervical carcinoma, to promote a healthy lifestyle.

\section{Conflict of interest}

The authors declare no conflict of interest.

\section{References}

1. Mariańczyk K, Steuden S. Oczekiwania oraz intencje zachowań zdrowotnych jako czynniki warunkujące wykonywanie profilaktycznej cytologii w grupie kobiet po 45 . roku życia. Psychoonkologia 2011; 2: 55-64.

2. Meder J. Podstawy onkologii klinicznej. Centrum Medyczne Kształcenia Podyplomowego, Warsaw 2011.

3. Podlińska M, Bernacka M, Gotlib J. Próba oceny wpływu wieku na poziom wiedzy na temat raka szyjki macicy wśród pacjentek hospitalizowanych w oddziale położniczo-ginekologicznym. Pielęgniarstwo XXI wieku 2010; 30: 57-63.

4. Słopiecka A, Kamusińska E. Analiza wiedzy i postawy kobiet $\mathrm{w}$ zakresie stanu zdrowia narządu rodnego, ze szczególnym uwzględnieniem badań cytologicznych. Zdrowie Publiczne 2004; 114: 29-36.

5. Reska D, Muszyska A, Grotowska M. Rak szyjki macicy - profilaktyka a świadomość społeczna. Fam Med Prim Care Rev 2006; 8: 740-2.

6. Chybicka A. Zalecenia grupy ekspertów dotyczące pierwotnej profilaktyki raka szyjki macicy u dziewcząt i młodych kobiet. Pediatr Pol 2010; 85: 4-14.

7. SpaczyńskiM,Nowak-MarkwitzE,Januszek-MichaleckaL, Karowicz-Bilińska A. Profil socjalny kobiet a ich udział w Programie Profilaktyki i Wczesnego Wykrywania Raka Szyjki Macicy w Polsce. Ginekol Pol 2009; 80: 833-8.

8. Czechowska K. Wiedzai zachowania prozdrowotnekobiet w zakresie profilaktyki raka szyjki macicy na podstawie badań pacjentek z powiatu jeleniogórskiego. In: Wiedza i doświadczenie pielęgniarki a jej działania promocyjno-edukacyjne. Pękała R (ed.). Wyższa Szkoła Medyczna LZDZ w Legnicy, Legnica 2008; 7-12.

9. Wojciechowska U, Didkowska J. Zachorowania i zgony na nowotwory złośliwe w Polsce. Krajowy Rejestr Nowotworów. Centrum Onkologii - Instytut im. Marii Skłodowskiej-Curie. Available at: http://onkologia.org.pl/raporty/; access on 28.10.2015.

10. Wojciechowska U, Didkowska J, Zatoński W. Pięcioletnie przeżycia chorych na nowotwory złośliwe w Polsce. Nowotwory J Oncol 2010; 60: 122-8.

11. Miśta S, Kurowska M, Włodarczak A. Szczepionki przeciwko zakażeniom wirusem HPV dla nastolatek - przełom $\mathrm{w}$ profilaktyce raka szyjki macicy. Klinika Nowa 2009; 16: 61-8.

12. Nowicki A, Borowa I, Maruszak M. Zachowania zdrowotne kobiet w zakresie zapobiegania, wczesnego wykrywania stanów przedrakowych i raka szyjki macicy. Ginekol Pol 2008; 79: 840-9.

13. Mastalerz-Migas A, Nowak A, Steciwko A. Wiedza i świadomość młodych kobiet w zakresie profilaktyki raka szyjki macicy. Fam Med Prim Care Rev 2011; 13: 443-5. 
14. Basta A, Pityński K. Rak szyjki macicy. In: Ginekologia onkologiczna. Markowska J, Mądry R (ed.). Wydawnictwo MedPharm Poland, Wrocław 2008; 103-13.

15. Bąk B, Sikorski M, Wrześniewska M. Health awareness among young women vaccinated against human papillomavirus infections. Studia Medyczne 2014; 30: 21-6.

16. Knihinicka-Mercik Z, Kazimierczak I, Mess E, Przestrzelska M. Styl życia kobiet przed rozpoznaniem raka szyjki macicy. Onkol Pol 2006; 9: 141-4.

17. Jacennik B. Kształtowanie zachowań zdrowotnych przez środowisko. Wizja Press \& It, Warsaw 2008.

18. Słopiecka A. Behaviour among women in the scope of cervical cancer prevention. Studia Medyczne 2013; 29: 287-92.

19. Przestrzelska M, Knihinicka-Mercik Z, Kazimierczak I, Mess E. Zachowania zdrowotne kobiet w profilaktyce nowotworu szyjki macicy i sutka. Onkol Pol 2006; 9: 172-5.

20. Derlatka P. Rak szyjki macicy. In: Chirurgia onkologiczna. Vol. 4. Jeziorski A, Szawłowski A, Towpik E (eds). PZWL, Warsaw 2010; 1323-6.

21. Olejniczak D, Bień M. The attitude of the female students of medical and non-medical fields of studies towards the cervical cancer prophylaxis. Studia Medyczne 2014; 30: 162-72.

22. Lipińska A, Karnia A, Włoch A, Lipińska-Stanczak M, Opuchlik A. The level of knowledge about risk factors for cervical cancer and health-related behaviours of women from the area of the Świętokrzyskie Region. Studia Medyczne 2014; 30: 196-202.

23. Krajewska M, Owłasiuk A, Litwiejko A. Stan wiedzy i zachowania zdrowotne mieszkanek Sejn odnośnie do profilaktyki raka szyjki macicy. Probl Med Rodz 2010; 12: 20-8.

24. Jokel M, Bielska-Lasota M, Kraszewska E. Zmiany uświadomienia i zachowań zdrowotnych kobiet dotyczace profilaktyki raka szyjki macicy w latach 1976, 1986, 1990 1998. Przegl Epidemiol 2001; 55: 323-30.

\section{Address for correspondence:}

Anna M. Lipińska MD, PhD

Institute of Physiotherapy

Faculty of Medicine and Health Science

Jan Kochanowski University

al. IX Wieków Kielc 19, 25-317 Kielce, Poland

Phone: +48413496954

E-mail: al.reha@wp.pl 